\title{
Artificial intelligence and big data in the Maritime Silk Road Initiative: The road towards Sea Power 2.0
}

\author{
Lungani Nelson Hlongwa ${ }^{465}$ \\ National Yang Ming Chiao Tung University (NYCU), Hsinchu, Taiwan
}

\begin{abstract}
China's Belt and Road Initiative continues to attract considerable attention from scholars and observers in diverse fields. However, students of the Belt and Road Initiative ('the Initiative') have focused extensively on the land and sea dimensions of this grand project while only tentatively touching on its other dimensions. This article draws attention to the digital and maritime dimensions of the Initiative, which are respectively known as the Digital Silk Road Initiative and the Maritime Silk Road Initiative. Specifically, the article focuses on how artificial intelligence and big data, as promoted under the Digital Silk Road Initiative, intersect with the Maritime Silk Road Initiative to produce what the author refers to as Sea power 2.0. To contextualise this intersection, the article draws on patent data to show how artificial intelligence and big data are adopted in supply chains. The results from the patent analysis show that artificial intelligence and big data will play a crucial role in future supply chains, and hence, the Maritime Silk Road Initiative. Although the article focuses mostly on the commercial side of Sea power 2.0, it concludes by pointing out how artificial intelligence and big data could serve military objectives.
\end{abstract}

Keywords: artificial intelligence, big data, supply chain, sea power, Maritime Silk Road Initiative.

\section{Introduction}

The Belt and Road Initiative (BRI) ('the Initiative') is China's vision of transcontinental and transoceanic economic integration through trade. This Initiative has various dimensions, most notably a land dimension known as the Silk Road Economic Belt (SREB) and a sea dimension known as the Maritime Silk Road Initiative (MSRI). ${ }^{466}$ Currently, there is a raging debate on what the BRI represents. Some observers see the BRI as presenting an opportunity for cooperative economic development for all countries concerned. ${ }^{467}$ Other observers view the BRI as China's grand strategic project to become an economic ${ }^{468}$ and technological superpower. ${ }^{469}$ Despite growing scholarship on the BRI, there remains a dearth of research beyond the land and sea dimensions. This article aims to examine the digital dimension of the BRI, which is officially known as the Digital Silk Road Initiative (DSRI). Specifically, the article draws attention to how artificial intelligence (AI) and big data, which are crucial components of the DSRI, may be used in the MSRI to produce what may be referred to as Sea power 2.0. 
The DSRI, which was first unveiled in 2015, is considered the technology arm of the BRI. It mainly focuses on internet interconnectivity, AI, the digital economy, and the construction of telecommunications technology, smart cities, and smart ports in BRI countries. ${ }^{470}$ As with the BRI at large, most researchers of the DSRI may be divided into two categories, which may be broadly categorised as 'promoters' and 'critics.' On the one hand, promoters view the DSRI as bringing much-needed technology to developing countries along the BRI. ${ }^{471}$ While the DSRI prioritises technology transfer from China to BRI countries, it is the nature of technologies being transferred that has drawn attention from critics. Some point out that, under the DSRI, China is exporting technologies that

authoritarian governments along the BRI may use for digital suppression. ${ }^{472}$ Furthermore, some critics argue that the DSRI is creating a new global digital order ${ }^{473}$ and laying the groundwork for China to project power abroad. ${ }^{474}$

This article attempts to address the following key question: what kind of power emerges from the entangling of the Digital and Maritime Silk Roads in the area of AI and big data? The author argues that what emerges from this intersection might be defined as Sea power 2.0 - the use of novel technologies, particularly those of Industry 4.0, to achieve commercial success at sea, which may be translated into strategic military advantage. Industry 4.0, or the fourth industrial revolution, refers to the ongoing automation of the industrial sector using modern technologies such as big data analytics, the Internet of Things (IoT), robotics, and AI, to mention a few. ${ }^{475}$ It is expected that Industry 4.0 will play an important role in fulfilling one of the major goals of global supply chains: bringing suppliers, producers, transportation services, and customers closer together. ${ }^{476}$

The definition of Sea power 2.0 is grounded in Alfred Thayer Mahan's conceptualisation of sea power, which is based on the intricate connection between commercial success at sea and naval power. For Mahan, sea power was primarily about securing the benefits of using the sea for 'one's own people'. ${ }^{477}$ Sea power 2.0, as it is being constructed through the Digital and Maritime Silk Roads, may be considered a way to secure similar benefits for 'one's own people' while also leaving room for others to benefit. This is certainly how the MSRI is being pushed - as a win-win approach to economic development for China and partner states. ${ }^{478}$

Methodologically, this study employed patent landscape analysis. The aim of the patent landscape was twofold: to frame the MSRI and the DSRI within the context of global supply chains and to show how AI and big data may be used in the MSRI. Following the introduction, this article is divided into four sections. The first section discusses the intersection between the MSRI and the DSRI. The second section provides a patent landscape to show how AI and big data are employed in global supply chains. The third section discusses how Sea power 2.0 operates, followed by a conclusion and recommendations for future research in the final section.

\section{The MSRI as a 'big data Initiative'}

As mentioned above, the MSRI is the sea dimension of the BRI. It was first proposed by Chinese President Xi Jinping in 2013 during his visit to Indonesia. ${ }^{479}$ In a speech 
delivered four years later at the Belt and Road Forum for International Cooperation ('BRI Forum') held in Beijing, President Xi referred to the BRI as the biggest project in the $21^{\text {st }}$ century that will benefit people worldwide. The BRI Forum was attended by 29 foreign heads of state, government representatives from over 130 countries, and over 70 representatives of international organizations. ${ }^{480}$ President Xi also pointed out connections between the BRI and the Ancient Silk Road, which connected China to the West via land and sea routes from the second century BCE until the eighteenth-century CE. He called on participating member states at the BRI Forum to embrace the spirit of the Ancient Silk Road, which was about friendly cooperation among nations with mutual interests. ${ }^{481}$

Figure 1 shows a map of the BRI. The MSRI starts in the Chinese coastal city of Fuzhou and then proceeds to Southeast Asia through the South China Sea. From Southeast Asia, the MSRI goes through the Malacca Strait into the Indian Ocean, touches on the east coast of Africa, and then via the Mediterranean to Europe. There are also plans to branch the MSRI out to New Zealand and create a new trade route across the Arctic known as the Polar Silk Road.

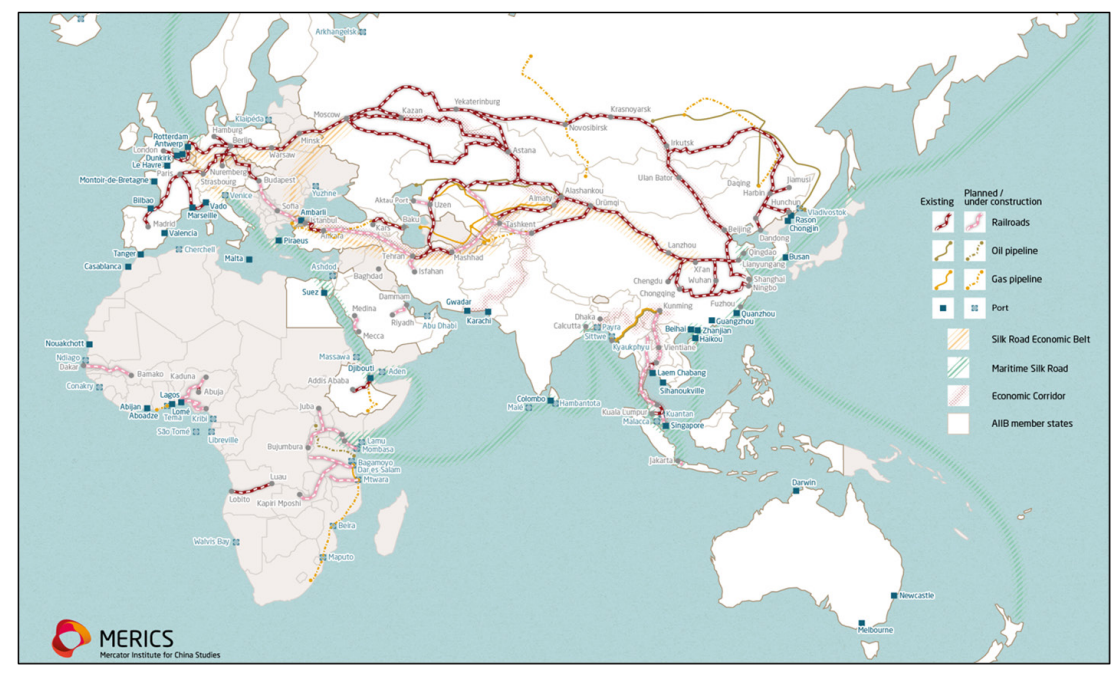

Figure 1: Map of the Belt and Road Initiative. 482

The BRI is grounded on a five-pronged approach: policy coordination, connectivity of infrastructure and facilities, unimpeded trade, financial integration, and closer peopleto-people ties. In turn, these approaches focus on eight fields, namely infrastructure connectivity, trade and economic cooperation, industrial investments, cooperation on energy resources, financial cooperation, people-to-people exchanges, ecological and environmental cooperation, and maritime cooperation. ${ }^{483}$ To date, China and dozens of BRI member states have made significant progress in some of these areas, notwithstanding many challenges and criticism. In Africa, for instance, China has 
invested billions of dollars in much-needed infrastructure, such as railways, seaports, and telecommunications technology, to mention but a few. ${ }^{484}$

On the one side of the scholarly literature on the MSRI and the BRI, scholars present the Initiative as a 'win-win' approach to cooperative development for participating member states. Many see the BRI as an engine for promoting economic growth for China and participating countries. ${ }^{485}$ Koboević et al. believe that the Initiative has neither political nor military aims as it is grounded in peaceful principles espoused in the United Nations Charter, namely mutual respect, equality, keeping promises, mutual benefits, and winwin development. ${ }^{486}$ Khan et al. also see the BRI as a model for promoting sustainable regional development among communities with shared interests. ${ }^{487}$ They contend that the BRI could fulfil the global demand for sustainable development, which requires, among others, job creation, poverty reduction, and cooperative economic development. ${ }^{488}$

On the other side of the BRI debate are observers who dismiss the purely win-win rhetoric surrounding the Initiative. Clarke argues that the BRI is China's grand strategy to resolve its domestic issues and to promote economic growth on which the Chinese Communist Party's (CCP) legitimacy depends. ${ }^{489}$ Contrary to Koboević et al., who argue that the BRI has no military dimension, ${ }^{490} \mathrm{Wu}$ and Ji contend that the Chinese military will be called on to deter threats to China's geo-economic expansion and safeguard the BRI. ${ }^{491}$ According to $\mathrm{Wu}$ and $\mathrm{Ji}$, the involvement of the Chinese military in the BRI gives the Initiative a clear military-security dimension whose geostrategic effect may be assessed through geopolitical lenses. ${ }^{492}$ The sea power lens, as applied in this study, is just one way of assessing the geopolitics of the MSRI.

The BRI is primarily funded by China through its various financial institutions. These include the Export-Import Bank of China (CEXIM), the China Development Bank (CDB) and the Silk Road Fund (SRF). ${ }^{493}$ China's lending for the construction of infrastructure in BRI countries has received wide criticism. To some observers, China is deliberately lending significant sums of money to BRI countries with the intended aim of capturing them in debt. This strategy of 'debt-trap diplomacy', the argument goes, could eventually lead indebted countries to surrender strategic assets to China. ${ }^{494}$ Sri Lanka's Hambantota Port, which was surrendered to China, is often used as an example of debttrap diplomacy. ${ }^{495}$ It is important to bear in mind that the BRI is still in its infancy. As the Initiative continues to unfold, time will give credence to or 'debunk' the theory of debt-trap diplomacy.

Another area of Chinese engagement in BRI countries that has received considerable criticism is China's digital diplomacy, which directly implicates the DSRI. Although the DSRI spans more than the maritime domain, it is in this context that the DSRI will be discussed. China's investment in the digital transformation of ports along the MSRI probably represents the clearest example of the fusion between the MSRI and the DSRI. Under the DSRI, China is constructing and upgrading ports with varying degrees of 'smartness' in various countries. In Greece, for example, a local subsidiary of China Ocean Shipping Company, Limited (COSCO) - a Chinese state-owned enterprise focusing on maritime transport - has transformed the Port of Piraeus through modern 
technology leading to a rapid increase in container throughput. ${ }^{496}$ Although COSCO's transformation of the Port of Piraeus started before the BRI was announced, the port is now considered the "dragon's head of the BRI" to denote its strategic importance to China's trade with Europe. ${ }^{497}$

According to a report by the Centre for Strategic and International Studies, there are about 46 ports that are either funded, constructed or operated by China in sub-Saharan Africa. ${ }^{498}$ The United States, which is wary of China's port investments on the continent, fears that these ports will align with Beijing's commercial, military and political objectives, among which is to provide a foothold for the Chinese Navy. ${ }^{499}$ The report states that Chinese port facilities in Africa might be used to collect intelligence and deny commercial access to competitors. ${ }^{500}$ However, the report also recognises a need for infrastructure experts and military strategists to collaborate in order to determine specific kinds of threats presented by specific port facilities. ${ }^{501}$

Another area where the MSRI and the DSRI come together is in AI and big data. 'Big data' refers to large and unstructured datasets characterised by six main components known as the six Vs: volume, velocity, variety, veracity, validity, and volatility. ${ }^{502}$ These components point to the quantity of data (volume), the pace at which data are generated (velocity), the various sources from which data may be obtained (variety), the biases and noise in the data (veracity), its accuracy for specific uses (validity), and the period of its validity and storage (volatility). ${ }^{503}$ Organisations utilising big data hope to gain actionable insights on their customers and products, streamline their operations, and unlock new opportunities to make a profit. ${ }^{504}$ The maritime industry, which produces data characterised by the six Vs, will also benefit from big data. ${ }^{505}$ For instance, data gathered from ships could be transmitted to onshore data centres, where such data are analysed to support a wide range of decisions. ${ }^{506}$ Port terminals may also utilise maritime big data to improve their operations and, ultimately, their competitiveness. ${ }^{507}$

Artificial intelligence, which generates insights from big data, also promises to transform the maritime industry. ${ }^{508}$ Initially developed to mimic human decision-making, AI now enables capabilities that were impossible just a decade ago. ${ }^{509}$ In the maritime industry, sophisticated AI systems are being developed to address issues related to sustainable energy, traffic accidents and congestion, logistic management, data analysis, security, and privacy ${ }^{510} \mathrm{It}$ is expected that $\mathrm{AI}$ and big data will play a crucial role in implementing the BRI. ${ }^{511}$ In his 2017 speech delivered at the BRI Forum, President Xi also called for advances to be made among BRI member states in the digital economy, AI, big data, cloud computing, and other technology areas. ${ }^{512}$ China's State Information Center has already established a BRI Big Data Center - a think-tank that aims to generate insights on trade along the BRI using big data. According to a report ${ }^{513}$ released by the BRI Big Data Center, in collaboration with other Chinese organisations, the insights generated will support government decision-making and serve the needs of enterprises and society. Therefore, it is fair to say that the BRI, in conjunction with the DSRI, is essentially a 'big data Initiative'. 
Some commentators point out that, through the DSRI, Beijing will have access to large datasets from BRI countries that can be analysed and exploited to China's advantage. ${ }^{514}$ How then might AI and big data be utilised to advance the MSRI? To help address this question, the following section provides a perspective through patents on how AI and big data may be employed in global supply chains. The patent landscape is intended to frame the MSRI and the DSRI within the larger context of global supply chains and maritime supply chains in particular.

\section{A patent perspective}

Before explaining how patents referred to in this study were obtained, it is necessary to discuss the idea behind patenting and the anatomy of the patent document. Patents are essentially legal monopoly rights granted by the state to inventors who disclose their inventions to the public. Patent rights are aimed at protecting inventors from having their inventions imitated by third parties. ${ }^{515}$ These rights are territorial, meaning that they generally apply in a specific country where a patent was filed. An exception to this is patents filed with the World Intellectual Property Organization (WIPO), which grants international patent protection. ${ }^{516}$

Anatomically, the patent document consists of several parts, including the title of the invention, an abstract section summarizing the invention, the background on the invention, and specific claims about the invention. Patent documents also reflect other information, such as important dates associated with the patent, the names of the inventor(s), and patent classification codes used to group technologies according to similarity. The two most common patent classification systems are the International Patent Classification (IPC) and Cooperative Patent Classification (CPC). ${ }^{517}$ The CPC system is based on the IPC but provides a more detailed classification of technologies.

In the technology and business environments, patent analysis has long been used to track technological development at firm or industry level, ${ }^{518}$ monitor competition, and identify innovation opportunities. ${ }^{519}$ While patents remain a largely under-utilised resource in the social sciences, several studies have employed patent data to probe social issues embedded in technology. Shapiro, for instance, utilised patent data to uncover how technology firms compete in the making of the smart city. ${ }^{520}$ For Shapiro, patents are a "medium of urban futuring" utilised by the urban technocrat to colonise the city. ${ }^{521}$ Delfanti and Frey also employed patent data to expose how Amazon uses its workers to automate its warehouses. ${ }^{522}$ The present study employed patents in a similar manner, that is, to show how power is embedded in technology. Borrowing from Shapiro, patents in the present context may be seen as mediums for 'maritime futuring' where power will be embedded in the substrate of technology.

To obtain patents for analysis, an online patent search and analysis tool called Patentcloud ${ }^{523}$ was used. A combined search using keywords and classification codes was conducted to retrieve documents related to AI and big data in the supply chain. ${ }^{524}$ Patents were retrieved from all patent databases around the world. The search, conducted on 2 July 2021, returned 22065 patent documents that were subsequently analysed. The data 
obtained are presented in two stages. The first stage will be on a global level covering supply chains in general. The second stage will focus specifically on Chinese patents for inventions related to maritime supply chains.

Figure 2 shows the top countries patenting in technologies related to AI and big data for supply chains. The United States dominates in this area with over 11000 patents. China is second on the list with 3945 patents. In 2019, China displaced the United States as the top filer of international patents with WIPO. ${ }^{525}$ The United States had been the top filer of international patents since 1978. According to former WIPO director-general Francis Gurry, China surpassing the United States in WIPO patents signals a shift in the locus of innovation from the West to the East. ${ }^{526}$ Despite being a newcomer in AI, China is making rapid progress in this technology as the country seeks to become an AI superpower. $^{527}$

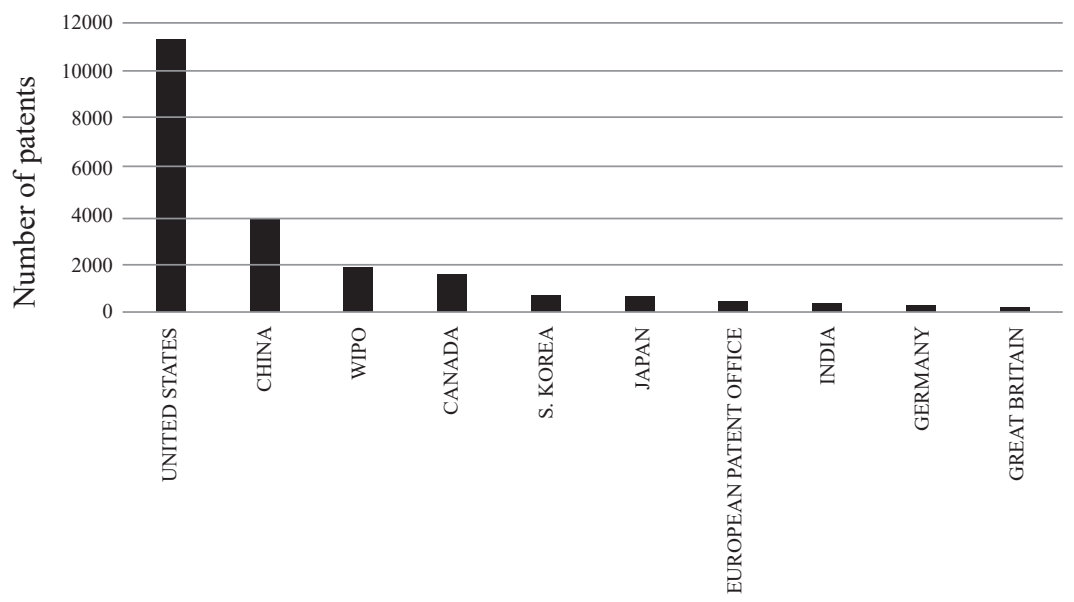

Figure 2: Top patenting countries in technologies related to AI and big data for the supply chain.

Figure 3 shows the patenting trends related to the application of AI and big data in supply chains. Patenting activity has increased rapidly since 2011. Due to a delay in patent publication, which is about 18 months in most jurisdictions, ${ }^{528} 2020$ and 2021 were omitted from Figure 3, as those years would have given a false decline in patent applications. However, it is evident from Figure 3 that AI and big data are in the rapid growth phase and will thus play a vital role in the future of supply chains. 


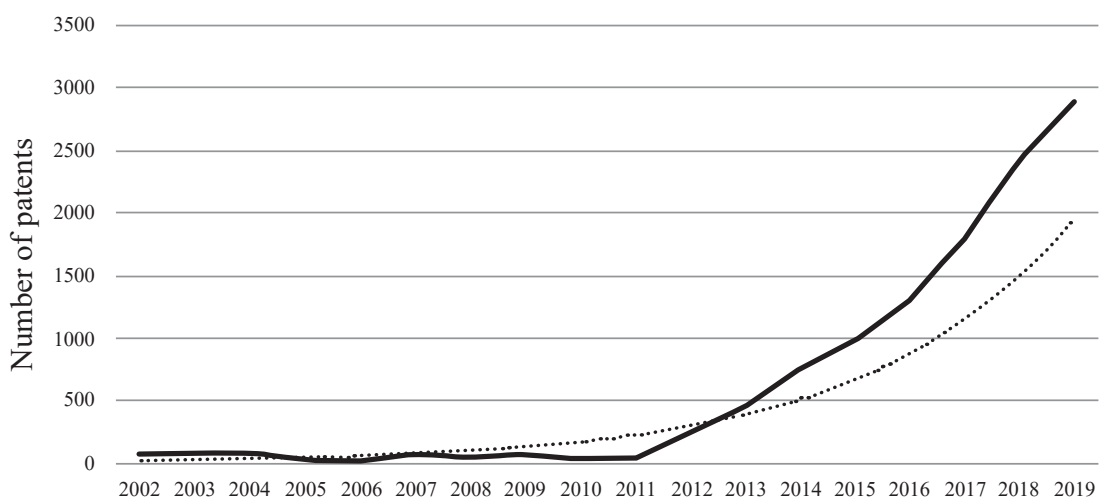

Figure 3: Patents related to AI and big data in the supply chain.

Using patent classification codes, it is possible to determine the technologies most actively patented. A high number of patents for a certain technology generally denotes more interest in that technology and tighter competition among patent holders. Based on Figure 4, systems and methods for data processing (G06Q and G06F) have seen the most patenting activity. Technologies related to the recognition of data $(\mathrm{G} 06 \mathrm{~K})$, wireless communication networks (H04W), and the transmission of digital information (H04L) also saw substantial patenting activity. Since supply chains today are governed by the just-in-time philosophy, it is no surprise that technologies related to transportation and storage $(\mathrm{B} 65 \mathrm{G})$, time or attendance registers (G07C), and measuring distance (G01C) are among the most actively patented.

At least two things can be said about the information presented in Figure 4. First, digital data will power the next generation of supply chains. This means that future supply chains will be run by algorithms crunching through data to find patterns, create various forms of intelligence, and aid decision-making in the supply chain and beyond. ${ }^{529} \mathrm{In}$ the case of the Digital and Maritime Silk Roads, market and shipping data gathered from member states may one day power China's AI algorithms that will enhance the country's production and shipping. ${ }^{530}$ Second, future maritime supply chains will be built on interconnected systems and networks that will facilitate the transmission of digital information. China is already laying the groundwork for such data transmission through the construction of smart ports, fibre optic cables, and data centres along the DSRI. ${ }^{531}$ 


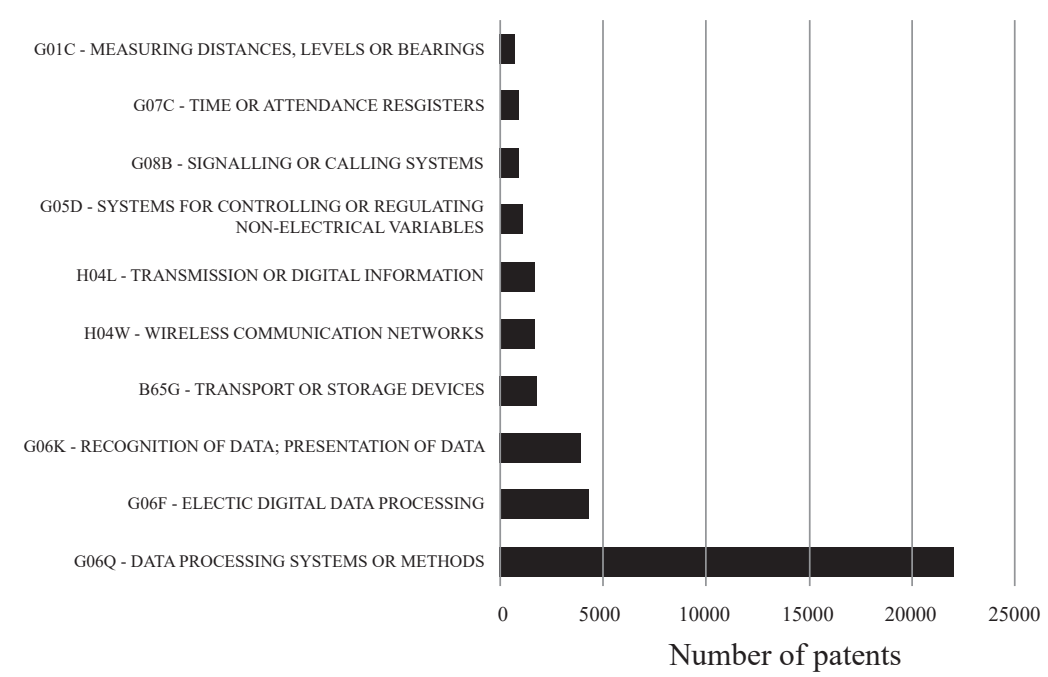

Figure 4: IPC classification of AI and big data patents related to the global supply chain.

Thus far, the data presented provided a macro perspective of patents related to AI and big data in the supply chain. The focus now turns to a micro-perspective where individual exemplary patents will be examined. A micro-level analysis is performed to confirm trends and associations found during a macro-level analysis. ${ }^{532}$ While the data presented above were for the broader supply chain, the focus here will be on those patents related to the maritime application of AI and big data. These patents were selected based on their relevance to the present discussion, that is, patents that can serve as an entry point to the discussion on Sea power 2.0. Furthermore, since the Digital and Maritime Silk Roads provided the context to study Sea power 2.0, only patents by Chinese applicants were considered. The aim was not to provide an exhaustive exposition of technologies but simply to show, through a few examples, how AI and big data could be used in the maritime supply chain and, by extension, the Digital and Maritime Silk Roads.

Table 1 presents six exemplary patents and a summary of how they apply AI and big data in the maritime supply chain. The first three patents relate to logistics and trade management systems. Among other applications, these patents use AI and big data to track commodity flows through the supply chain and improve logistics arrangements and customs clearance for goods. The fourth and fifth patents related to improving port operations using AI and big data. The fourth patent uses big data to improve the efficiency of ports by running them in a business-like manner. The fifth patent uses $\mathrm{AI}$ and cloud computing technology to make the process of receiving and dispatching cargo more efficient. The final patent is for tracking and analysing the trade of bulk commodities. This latter invention uses big data related to maritime transport and ship data to analyse the international trade of bulk commodities and present that information visually. 
Table 1: Exemplary Chinese patents related to the maritime supply chain.

\begin{tabular}{|c|c|c|}
\hline Document No. & Assignee/patent title & Brief summary \\
\hline CN111882275A & $\begin{array}{l}\text { Zhejiang Shangqingda } \\
\text { Trade big data management } \\
\text { method and system based } \\
\text { on industrial identification } \\
\text { analysis }\end{array}$ & $\begin{array}{l}\text { This patent discloses a trade } \\
\text { management platform built on big } \\
\text { data. The invention captures data on } \\
\text { commodities as they flow through the } \\
\text { supply chain and share the data among } \\
\text { suppliers of raw materials, producers } \\
\text { and manufactures, logistics and } \\
\text { transportation services, and distributors } \\
\text { to final users. }\end{array}$ \\
\hline CN112686754A & $\begin{array}{l}\text { Chongqing College of Finance } \\
\text { and Economics } \\
\text { International trade information } \\
\text { management system }\end{array}$ & $\begin{array}{l}\text { This patent discloses an international } \\
\text { trade information management system } \\
\text { that uses AI to improve logistics } \\
\text { arrangements and the customs clearance } \\
\text { of goods. }\end{array}$ \\
\hline CN108776878A & $\begin{array}{l}\text { Hubei Di Tian Mdt Infotech } \\
\text { Logistics cloud big data } \\
\text { information platform }\end{array}$ & $\begin{array}{l}\text { This patent discloses a logistics } \\
\text { information management system based } \\
\text { on big data. The invention includes } \\
\text { a two-way logistics information } \\
\text { management platform that interfaces } \\
\text { with users. This invention extracts user } \\
\text { data and integrates it with other data to } \\
\text { facilitate the shipment of goods. }\end{array}$ \\
\hline CN112070426A & $\begin{array}{l}\text { Jiangsu Hongtai Logistics } \\
\text { Wharf business-based big data } \\
\text { intelligent management system }\end{array}$ & $\begin{array}{l}\text { The invention disclosed in this patent } \\
\text { is an intelligent port management } \\
\text { system based on big data. The invention } \\
\text { comprises a logistics business module, a } \\
\text { processing operation module, a financial } \\
\text { module, and a file management module. } \\
\text { Combined, these modules run a port } \\
\text { like a business and aim to make port } \\
\text { operations more efficient. }\end{array}$ \\
\hline CN111626576A & $\begin{array}{l}\text { Shanghai Box Cloud Logistics } \\
\text { Technology } \\
\text { Cloud-centralised } \\
\text { transportation mode }\end{array}$ & $\begin{array}{l}\text { This patent is intended for a } \\
\text { cloud-based cargo collection and } \\
\text { transportation system. It aims to make } \\
\text { port operations more efficient by } \\
\text { using cloud computing for storing and } \\
\text { processing information related to cargo } \\
\text { and AI technology for cargo inspection. }\end{array}$ \\
\hline CN109948968A & $\begin{array}{l}\text { Chuanbo Data Tech Shanghai } \\
\text { Co. Ltd } \\
\text { A bulk commodity trade } \\
\text { logistics tracking analysis } \\
\text { method }\end{array}$ & $\begin{array}{l}\text { This invention can be used for tracking } \\
\text { and analysing the trade of bulk } \\
\text { commodities. An intelligent analysis } \\
\text { method, which uses ship data and } \\
\text { maritime transport big data, tracks the } \\
\text { international transportation of bulk } \\
\text { cargo and presents that information in a } \\
\text { visual mode. }\end{array}$ \\
\hline
\end{tabular}


The exemplary patents presented above only show a glimpse of what would be possible through the successful integration of the Digital and Maritime Silk Roads. Some of these inventions aim to achieve data integration between suppliers of raw materials, producers, logistics services, and global markets through AI and big data. On the other hand, some inventions aim to transform the traditional labour-intensive seaport, a crucial interface between land and sea, into a more efficient and globally competitive facility. Given the exclusionary nature of patents, where the patent haves exclude the patent have-nots from key technologies, it is easy to see how patents play into the power dynamic among states. While building the Digital and Maritimes Silk Roads, China is simultaneously laying the technological foundation to grow its dominance in global trade, as seen in the patents. In other words, China is on the march to becoming a sea power of the first order. ${ }^{533}$

\section{Towards Sea Power 2.0}

This section discusses the notion of Sea power 2.0, which is grounded in the work of Alfred Thayer Mahan - a nineteenth-century American navy captain and naval theorist who coined the term 'sea power'. While relying on nineteenth-century ideas to explain a twenty-first-century phenomenon may seem at odds, Mahan remains a central figure among students of naval history and naval strategy. ${ }^{534}$ As Holmes points out, although Mahan's writing about naval warfare may be outdated, his "meditations on the logic of sea power - a logic founded on commerce, bases, and ships, and on commercial, political, and military access to important theatres - appear everlasting". ${ }^{535}$ Mahan's work continues to influence naval thinkers around the world. He is also widely read among Chinese naval thinkers as China looks to become a sea power nation. ${ }^{536}$

It is worth considering America's economic conditions that led Mahan to propose his theory of sea power. Towards the end of the nineteenth century, American capitalism was in a state of crisis. Like China today, America had a huge industrial overcapacity that required expanded markets for its manufactured goods. Recognising the limits of its domestic market, Mahan called on America to expand overseas in search of foreign markets. ${ }^{537}$ David Harvey, a Marxist geographer, refers to this strategy of resolving the capitalist crisis of over-accumulation by expanding spatially as the 'spatial fix'. ${ }^{338}$ Mahan provides his theory of sea power in his influential book titled The influence of sea power upon history: 1660-1783. ${ }^{539}$ This section does not provide a comprehensive reappraisal of Mahan's sea power theory but simply points out those principles relevant to the discussion on Sea power 2.0.

Mahan believed that the propensity to trade and the production of something to trade with is the national characteristic most vital for developing sea power. For Mahan, the industrial capability of a country is, therefore, an important determinant of its ability to become a sea power. Another important ability of a sea power nation, according to Mahan, is the ability to establish colonies or markets to absorb manufactured commodities from a mother country. Such colonies were established by either friendly or forceful means. However, regardless of how these colonies were founded, Mahan argued: 
[I]n both cases the mother-country had won a foothold in a foreign land, seeking a new outlet for what it had to sell, a new sphere for its shipping, more employment for its people, more comfort and wealth for itself. ${ }^{540}$

Between these two - production and colonies - Mahan wrote, "shipping is the inevitable link" ${ }^{541}$ Figure 5 is a representation of Mahan's sea power model.

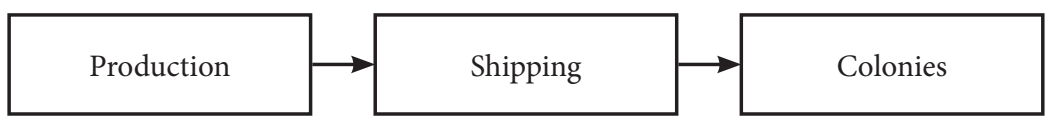

Figure 5. Mahan's sea power model.

Another important aspect of Mahan's concept of sea power is the need for foreign bases along one's trade routes. Such bases were established not so much for trade but primarily for defence and war. The character of these foreign facilities was either commercial or military or both. For Mahan, sea power ultimately boiled down to decisive battle at sea. He wrote extensively about the history of naval warfare, to which he dedicated a great part of his influential book. Despite Mahan's naval-centric conception of sea power, he recognised that power at sea "embraces in its broad sweep all that tends to make a people great upon the sea or by the sea". ${ }^{542}$ Relevant to the discussion here is Mahan's concept of 'staying power' - that which indirectly contributes to maritime greatness. An example that Mahan refers to is "a large number of people engaged in the various handicrafts which facilitate the making and repairing of naval material or following other callings more or less closely connected with the water and with craft of all kinds". ${ }^{543}$

The MSRI, as it is currently unfolding, seems to align very much with Mahan's sea power model, although with some notable differences. Some observers have even argued that China's pursuit of sea power is Mahanian but with "Chinese characteristics". ${ }^{544}$ What then are the Mahanian features of the MSRI? First, the MSRI was introduced to take advantage of China's industrial productivity. Being the world's manufacturing and trade powerhouse, China more than meets the first requirement of being a sea powerthe tendency to trade and the production of something with which to trade. The MSRI has also been considered China's spatial fix to resolve its issue of over-accumulation. ${ }^{545}$ China is, after all, in the same situation today as America was towards the end of the nineteenth century when it felt the need to become a sea power. Therefore, it can be said that, with the MSRI, China is pursuing a strategic alliance between its productive sector, shipping industry and overseas markets.

Second, China's need for ports along the MSRI aligns with Mahan's principle of establishing foreign facilities for strategic defence. ${ }^{546}$ Some analysts believe that, with the MSRI, China is pursuing dual logistics and military bases along the Indian Ocean. The first overseas naval base of the People's Liberation Army (PLA) Navy in Djibouti is often a case in point. ${ }^{577}$ China's decision to establish a military facility in Djibouti came as a surprise since China has long been opposed to setting up military bases abroad. ${ }^{548}$ Third, due to the extreme sensitiveness of maritime trade, the success of the MSRI 
will depend on a blue water navy capable of protecting China's sea commerce in farflung oceans. ${ }^{549}$ This strategic link between sea commerce and the navy is one of the seemingly 'everlasting' principles of Mahanian sea power. Based on the three principles above, it is safe to say that with the MSRI, China is pursuing sea power with some Mahanian characteristics.

There are two issues worth clarifying in the present discussion on Sea power 2.0. The first is how Mahan saw the colony in his time in relation to how we might see it today. Being a proponent of imperial expansion, Mahan saw colonies as either markets for American manufactured goods, reservoirs for natural resources, or both. For Mahan, imperialism thus had both a market logic and an extractive logic. In today's digital age where data drive capitalism, critical data scholars and those studying new forms of colonialism have suggested we rethink the colony. ${ }^{550}$ Couldry and Mejias, for instance, argue that we might think of the extraction of big data from the Global South by the Global North for capital production as "data colonialism". ${ }^{551}$ For Couldry and Mejias, data colonialism is a new form of colonialism distinctive to the twenty-first century but maintains its predatory extractive practices of historical colonialism. According to these authors, there are at least two poles of data colonialism, namely the United States and China, which operate internally and externally.

China's growing access to data along the BRI has raised suspicions of what Gravett refers to as "digital colonialism". ${ }^{552}$ In the present discussion on Sea power 2.0, the concept of the colony will be maintained to highlight its role as both a market and a site of data extraction. However, this does not suggest that all BRI states are perceived in this manner, as that would have to be determined on a case-by-case basis. What is crucial is to understand the role of the colony in the Sea power 2.0 model.

The second issue is how production, shipping and colonies relate to one another. In Mahan's days, these were certainly not as connected given the state of technology at the time. Today, however, production, shipping and colonies are becoming intricately connected through Industry 4.0 technologies enabled by big data. Going back to the exemplary patents provided in the previous section, inventions - such as the trade big data management platform - embody the desired interconnectedness between production, shipping and colonies through the continuous flow of data. At the same time, inventions - such as the intelligent port management system and the cloud-based cargo collection and transportation system - embody visions of unbounded trade using AI and big data. It is precisely this growing interconnection between production, shipping and colonies that is giving rise to Sea power 2.0. In the Sea power 2.0 model (see Figure 6), 'the cloud' represents a new 'spatial' domain that supports the storage and computation capabilities of big data flowing to and from production, shipping, and colonies. In this model, the data colony would be one whose data are extracted and utilised to inform the production processes, shipping, and market intelligence of a sea power state. 


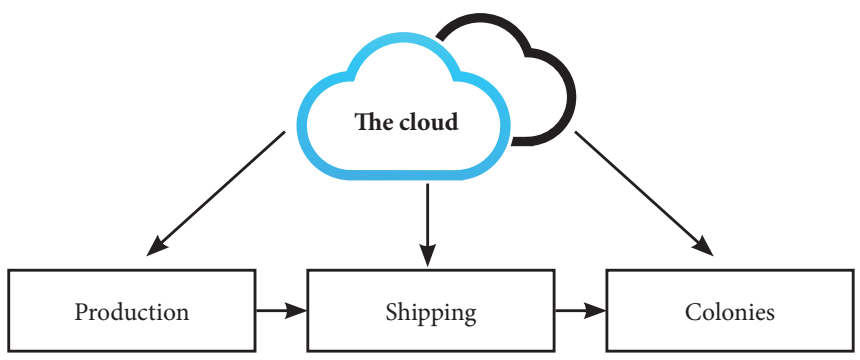

Figure 6. Author's adaptation of Mahan's sea power model.

How then might the intersection between the Maritime and Digital Silk Roads further illustrate how Sea power 2.0 operates? The operations of Sea power 2.0 may be understood from two perspectives - commercial and military. From a commercial perspective, big data is extracted from BRI member states and utilised by China to inform its production, shipping, and quest for overseas markets. Big data flowing to China would include various kinds of market data and shipping data, which China could use to its advantage. ${ }^{553}$ Examples of market data include data extracted from e-commerce platforms and mobile payments, which would allow Chinese firms to discern the spending habits of their foreign customers and dominate future products. ${ }^{554}$ Shipping data would include but are not limited to data centralised at smart ports and data on global commodity flows, both of which will offer China great command over global trade. ${ }^{555}$

In the Sea power 2.0 model, power is embedded in data relations between data owners and producers. Those who own data utilise it as a strategic resource for capital production through maritime commerce and related sectors. Although China's partner states stand to benefit from the construction of information and communications technology (ICT), the risk is that Chinese firms will use their market data advantage enabled by cloud-based servers and e-commerce to dominate BRI markets and potentially undermine the growth of local tech firms. ${ }^{556}$ At the national level, control over digital data is also becoming an important determinant of the ability to compete in global value chains. ${ }^{557}$ Access to data along the BRI could thus put China in an advantageous position in national economic competitiveness. ${ }^{558}$

Sea power 2.0 may also be understood from a military perspective. Although by no means the only one, a crucial issue relates to the strategic military advantage that might be gained from seeing the MSRI as a 'big data Initiative'. Might big data gathered from the MSRI function as a form of 'staying power' to achieve commercial and military superiority at sea? China's dual-use model - which blurs the lines between civilian and military facilities and resources ${ }^{559}$ - makes it entirely possible that big data from the MSRI might be used to support decisions involving the PLA Navy. Russel and Berger point out that big data harvested from the BRI can be used to support the capabilities of the PLA in what the military refers to as C4ISR - Command, Control, Communications, Computers (C4), Intelligence, Surveillance and Reconnaissance (ISR).$^{560}$ 
The dual civilian-military model also applies to AI. According to China's national AI development plan, China aims to strike a strategic alliance between civilian and military development and the use of AI. ${ }^{561}$ According to China's AI development plan, this alliance would allow China to use AI to build both its economy and its defence capabilities. From a Mahanian perspective, this new data and AI-enabled link between sea commerce and naval power is the crux of what the current author refers to as Sea power 2.0. While the article has dedicated significant space discussing the commercial side of Sea power 2.0, the naval side equally matters. Herein lies potential for future research on the naval dimension of Sea power 2.0.

\section{Conclusion}

The study reported in this article pursued the following research question: what kind of power is baked into the intersection between the Digital and Maritime Silk Roads in the area of AI and big data? The author argued that what emerges from this intersection may be referred to as Sea power 2.0, that is, the use of novel technologies, particularly those of Industry 4.0, to achieve commercial success at sea, which can be translated into strategic military advantage. To support this argument, the article first framed the MSRI within the larger global supply chain. Focusing specifically on AI and big data, a patent landscape was conducted to show how these technologies are transforming the global supply chain more generally and the maritime supply chain in particular. The patent landscape revealed, among other results, the growing interconnectedness between producers, shipping, and markets through AI and big data. The exemplary patents presented also revealed that China hopes to use AI and big data to grow its dominance in global trade. These results served as an entry point to the theorisation of Sea power 2.0.

The article discussed two perspectives to see how Sea power 2.0 operates. The first relates to the extraction of market and shipping big data to support the growth of maritime commerce. Using the Digital and Maritime Silk Roads as context, it was argued that, through their integration, China would gain greater access to market and shipping data of partner states. Such data would allow Chinese enterprises to discern their foreign markets more accurately; thus, enabling them to dominate BRI markets. In this data-mediated relationship among states, power is embedded in the data relations among them where the data haves stand to benefit more, or even at the expense of the data have nots.

The second perspective to observe Sea power 2.0 in operation is through a military lens. In the context of the PLA Navy, big data gathered along the MSRI may be used to support military decisions. It was argued that this data-enabled link between maritime commerce and naval power constitutes the essence of Sea power 2.0. Furthermore, China hopes to utilise AI for both economic growth and defence construction. As some have pointed out, China is on track to become an AI superpower. There is indeed much that remains unsaid about the concept of Sea power 2.0. Future research could consider showing in greater detail how Sea power 2.0 operates. Studies focusing on how Sea power 2.0 benefits are derived and how it can be resisted would also contribute to testing the value of the concept. 


\section{ENDNOTES}

${ }^{465}$ Lungani Nelson Hlongwa is a PhD candidate at the Institute for Social Research and Cultural Studies at National Yang Ming Chiao Tung University in Taiwan. He obtained his MSc degree in technology management from Chung Hua University (Taiwan) with a specialisation in patent analytics. He is also a former student of the Faculty of Military Science of Stellenbosch University where he obtained his Bachelor of Military Science degree. The author is grateful to the CHCI-Global Humanities Institute for supporting this research and to the reviewers at Scientia Militaria for their insightful comments, which improved the manuscript. The author can be contacted at lungani.srcs08g@nctu.edu.tw

${ }^{466}$ P Cai. "Understanding China's Belt and Road Initiative”. Lowy Institute, 22 March 2017. $<$ https://www.lowyinstitute.org/publications/understanding-belt-androad-initiative $>$ Accessed on 12 July 2021.

${ }^{467}$ MK Khan, IA Sandano, CB Pratt \& T Farid. "China's Belt and Road Initiative: A global model for an evolving approach to sustainable regional development". Sustainability 10/11. 2018. 4234.

${ }^{468}$ Cai op. cit.

${ }^{469}$ C Cheney. "China's Digital Silk Road: Strategic technological competition and exporting political illiberalism". Pacific Forum, July 2019. $<$ https://pacforum.org/wp-content/ uploads/2019/08/issuesinsights_Vol19-WP8FINAL.pdf> Accessed on 12 July 2021.

${ }^{470}$ CR Mohan \& CJ Hao. "China's digital expansion and India". ISAS Working Paper, 8 October 2019. $<\underline{\text { https://www.isas.nus.edu.sg/wp-content/uploads/2019/10/ISAS-Working- }}$ Paper-No.-320.pdf $>$ Accessed on 12 July 2021.

${ }^{471}$ I Lazanyuk \& S Revinova. "Digital Silk Road as an integration project: Opportunities for Russia”. Paper presented at the 2nd International Scientific and Practical Conference "Modern Management Trends and the Digital Economy: From Regional Development to Global Economic Growth", Yekaterinburg, 16-17 April 2020.

${ }^{472}$ J Kurlantzick. "China's Digital Silk Road Initiative: A boon for developing countries or a danger to freedom?" The Diplomat. 17 December 2020. $<$ https://thediplomat. com/2020/12/chinas-digital-silk-road-initiative-a-boon-for-developing-countries-or-adanger-to-freedom/> Accessed on 12 July 2021.

${ }^{473}$ R Ghiasy \& R Krishnamurthy. "China's Digital Silk Road and the global digital order". The Diplomat. 13 April 2021. <https://thediplomat.com/2021/04/chinas-digital-silk-roadand-the-global-digital-order/> Accessed on 12 July 2021.

${ }^{474}$ Cheney op. cit.

${ }^{475}$ M Abdirad \& K Krishnan. "Industry 4.0 in logistics and supply chain management: A systematic literature review”. Engineering Management Journal 33/3. 2021. 187-201.

${ }^{476}$ Ibid

${ }^{477}$ AT Mahan. "The influence of sea power upon history, 1660-1783". The Project Gutenberg eBook. 26 September 2004. <http://www.gutenberg.org/files/13529/13529-h/13529-h. $\mathrm{htm}>$ Accessed on 12 July 2021.

${ }^{478}$ Z Koboević, Z Kurtela \& S Vujičić. "The Maritime Silk Road and China's Belt and Road Initiative". NAŠE MORE: znanstveni časopis za more i pomorstvo 65/2. 2018. 113122.

${ }^{479}$ JMF Blanchard \& C Flint. "The geopolitics of China's Maritime Silk Road Initiative". Geopolitics 22/2. 2017. 223-245.

${ }^{480}$ See link for more information on the BRI Forum: http://english.www.gov.cn/news/video/2017/05/12/content 281475653319187.htm 
${ }^{481} \mathrm{~J} \mathrm{Xi}$. "Work together to build the Silk Road Economic Belt and the twenty-first century Maritime Silk Road". Xinhua. 16 May 2017. $<\underline{\text { http://www.xinhuanet.com// }}$ english/2017-05/16/c 136287878.htm> Accessed on 12 July 2021.

482 TS Eder. "Mapping the Belt and Road Initiative: This is where we stand". Mercator Institute for China Studies, 7 June 2018. < $\underline{\text { https://merics.org/en/tracker/mapping-belt-and-road- }}$ initiative-where-we-stand $>$ Accessed on 25 August 2021.

${ }^{483}$ H Shang. The Belt and Road Initiative: Key concepts. Singapore: Springer Singapore, 2019.

${ }^{484}$ F Kaczmarek. "African dimension of the Belt and Road Initiative”. Przeglad Strategiczny 9/12. 2019. $145-160$.

${ }^{485}$ Koboević et al. op. cit.

${ }^{486} \mathrm{Ibid}$.

${ }^{487}$ Khan et al. op. cit.

${ }^{488} \mathrm{Ibid}$.

${ }^{489}$ M Clarke. "The Belt and Road Initiative: China’s new grand strategy?” Asia Policy 24/1. 2017. 71-79.

${ }^{490}$ Koboević et al. op. cit.

${ }^{491}$ X Wu \& Y Ji. "The military drivers of China's Belt and Road endeavor". China Review 20/4. 2020. 223-244.

${ }^{492}$ Ibid

${ }^{493}$ W Liu, Y Zhang \& W Xiong. "Financing the Belt and Road Initiative". Eurasian Geography and Economics 61/2. 2020. 137-145.

${ }^{494}$ B Chellaney. "China’s debt-trap diplomacy”. Project Syndicate, 23 January 2017. $<\underline{\text { https:// }}$ www.project-syndicate.org/commentary/china-one-belt-one-road-loans-debt-bybrahma-chellaney-2017-01?barrier=accesspaylog $>$ Accessed on 12 July 2021.

${ }^{495}$ Ibid.

${ }^{496}$ B Neilson. "Precarious in Piraeus: On the making of labour insecurity in a port concession". Globalizations 16/4. 2019. 559-574.

${ }^{497}$ A Brînză. "How a Greek port became a Chinese "dragon head"”. The Diplomat. 25 April 2016. $<\underline{\text { https://thediplomat.com/2016/04/how-a-greek-port-became-a-chinese-dragon-head/ }>}$ Accessed on 12 July 2021.

${ }^{498}$ JE Hillman. "Influence and infrastructure: The strategic stakes of foreign projects". Center for Strategic and International Studies, 22 January 2019. $<\underline{\text { https: } / / \text { csis-website- }}$ prod.s3.amazonaws.com/s3fs-public/publication/190123_Hillman InfluenceandInfrastructure WEB v3.pdf $>$ Accessed on 12 July 2021.

${ }^{499}$ Ibid.

${ }^{500} \mathrm{Ibid}$.

${ }^{501}$ Ibid.

${ }^{502}$ E Hamoudy. “Analyzing 6Vs of Big Data using System Dynamics”. Journal of Kerbala University 7/4. 2011. 75-83.

${ }^{503} \mathrm{Ibid}$

${ }^{504} \mathrm{C}$ Ogrean. "Relevance of big data for business and management: Exploratory insights (Part I)". Studies in Business and Economics 13/2. 2018. 153-163.

${ }^{505}$ M Mirović, M Miličević I \& Obradović. "Big data in the maritime industry". NAŠE MORE: znanstveni časopis za more i pomorstvo 65/1.2018. 56-62.

${ }^{506} \mathrm{Ibid}$.

${ }^{507}$ M Jović, E Tijan, R Marx \& B Gebhard. "Big data management in maritime transport". Pomorski zbornik 57/1. 2019. 123-141.

${ }^{508}$ ZH Munim, M Dushenko, VJ Jimenez, MH Shakil \& M Imset. "Big data and artificial intelligence in the maritime industry: A bibliometric review and future research directions". Maritime Policy \& Management 47/5. 2020. 577-597.

${ }^{509}$ Ibid. 
${ }^{510}$ MD Lytras, KT Chui \& RW Liu. "Moving Towards Intelligent Transportation via Artificial Intelligence and Internet-of-Things". Sensors 20/23. 2020. 1-4.

${ }^{511}$ A Liu \& P Guan. "Big data technology application under belt and road initiative". Paper presented at the 2017 Second Russia and Pacific Conference on Computer Technology and Applications, Vladivostok, Russky Island, 25-29 September 2017.

${ }^{512} \mathrm{Xi}$ op. cit.

513 The report, which is in Mandarin, may be found at this link: https://www.yidaiyilu.gov.cn/ wcm.files/upload/CMSydylgw/201703/201703241243039.pdf

${ }^{514}$ J Hemmings. "Reconstructing order: The geopolitical risks in China's Digital Silk Road". Asia Policy 27/1. 2020. 5-21.

${ }^{515}$ A Trippe. "Guidelines for preparing patent landscape reports". World Intellectual Property Organization, 2015. <https://www.wipo.int/edocs/pubdocs/en/wipo_pub_946.pdf> Accessed on 12 July 2021.

${ }^{516}$ Ibid.

${ }^{517}$ Ibid.

${ }^{518}$ Ibid.

${ }^{519}$ H Dou, V Leveillé, S Manullang \& JM Dou Jr. "Patent analysis for competitive technical intelligence and innovative thinking". Data Science Journal 4. 2005. 209-236.

${ }^{520}$ A Shapiro. "'Embodiments of the invention': Patents and urban diagrammatics in the smart city". Convergence 26/4. 2020. 751-774.

${ }^{521}$ Ibid.

${ }^{522}$ A Delfanti \& B Frey. "Humanly extended automation or the future of work seen through Amazon patents". Science, Technology, \& Human Values 46/3. 2021. 655-682.

${ }^{523}$ PatentCloud is a patent search and analysis software and may be accessed through this link: https://app.patentcloud.com/

${ }^{524}$ Keywords and patent classification codes used to search for patents: ((ICL/(G06Q10/08)) OR(ICL/(G06Q50/28)))AND((ICL/(G06F or 15/18))OR(TAC/(G06F or 19/24)) OR(TAC/(G06F or 30/27))OR(TAC/(G06N or 20/00))OR(TAC/("big data" or 大数 据))OR(TAC/("artificial intelligence" or 人工智能))).

${ }^{525}$ See this link for more information on WIPO patent filing: https://www.wipo.int/pressroom/en/ articles/2020/article_0005.html

${ }^{526}$ Ibid.

${ }^{527}$ K Lee. AI superpowers: China, Silicon Valley, and the new world order. Wilmington, MA: Houghton Mifflin Harcourt, Mariner Books, 2018.

${ }^{528}$ Trippe op. cit.

${ }^{529}$ M Seyedan \& F Mafakheri. "Predictive big data analytics for supply chain demand forecasting: methods, applications, and research opportunities". Journal of Big Data 7/1. 2020. $1-22$.

${ }^{530}$ Hemmings op. cit.

${ }^{531}$ A Wheeler. "China's Digital Silk Road (DSR): The new frontier in the digital arms race". Silk Road Briefing. 19 February 2020. < https://www.silkroadbriefing.com/ news/2020/02/19/chinas-digital-silk-road-dsr-new-frontier-digital-arms-race/ > Accessed on 2 November 2021.

${ }^{532}$ Hemmings op. cit

${ }^{533}$ JJ Nohara. "Sea power as a dominant paradigm: The rise of China's new strategic identity". Journal of Contemporary East Asia Studies 6/2. 2017. 210-232.

${ }^{534}$ B Armstrong. Twenty-first century Mahan: Sound military conclusions for the modern era. Annapolis, MD: Naval Institute Press, 2013.

${ }^{535}$ JR Holmes. "China's naval strategy: Mahanian ends through Maoist means". The Diplomat. 21 June 2013. $<\underline{\text { https://thediplomat.com/2013/06/chinas-naval-strategy-mahanian- }}$ ends-through-maoist-means/> Accessed on 12 July 2021. 
${ }^{536}$ W Zhang \& S Ahmed. “A general review of the history of China's seapower theory development". Naval War College Review 68/4. 2015. 80-93.

${ }^{537}$ Mahan op. cit.

${ }^{538}$ D Harvey. "Globalization and the "spatial fix"'. Geographische revue: Zeitschrift für Literatur und Diskussion 3/2. 2001. 23-30.

${ }_{539}$ Mahan op. cit.

${ }^{540}$ Ibid., p. 195.

${ }^{541}$ Ibid., p. 221.

${ }^{542}$ Ibid., p. 117.

${ }^{543}$ Ibid., pp. 246-247.

${ }^{544}$ Z Keck. "Alfred Thayer Mahan with Chinese characteristics". The Diplomat. 1 August 2013. $<$ https:/thediplomat.com/2013/08/alfred-thayer-mahan-with-chinese-characteristics/> Accessed on 12 July 2021.

${ }^{545}$ P Carmody, I Taylor \& T Zajontz. "China's spatial fix and 'debt diplomacy' in Africa: Constraining belt or road to economic transformation?" Canadian Journal of African Studies/Revue canadienne des études africaines. 2021. 1-21.

${ }^{546}$ See this link for US congress members drawing parallels between the MSRI and Mahan's sea power theory: https://www.congress.gov/116/chrg/CHRG-116hhrg41367/CHRG116hhrg41367.pdf

${ }^{547}$ J Drun. "China's maritime ambitions: A sinister string of pearls or a benevolent Silk Road (or both)?" Center for Advanced China Research, 6 December 2017. $<$ https://www. ccpwatch.org/single-post/2017/12/05/china-s-maritime-ambitions-a-sinister-string-ofpearls-or-a-benevolent-silk-road-or-both> Accessed on 12 July 2021.

${ }^{548}$ JP Cabestan. "China's military base in Djibouti: A microcosm of China's growing competition with the United States and new bipolarity". Journal of Contemporary China 29/125. 2020. 731-747.

${ }^{549} \mathrm{Wu} \& \mathrm{Ji}$ op. cit.

${ }^{550}$ JO Thatcher, D O'Sullivan \& D Mahmoudi. "Data colonialism through accumulation by dispossession: New metaphors for daily data". Environment and Planning D: Society and Space 34/6. 2016. 990-1006.

${ }^{551}$ N Couldry \& UA Mejias. "Data colonialism: Rethinking big data's relation to the contemporary subject". Television \& New Media 20/4. 2019. 336-349.

${ }^{552}$ WH Gravett. "Digital coloniser? China and artificial intelligence in Africa". Survival 62/6. 2020. 153-178.

${ }_{553}^{55}$ Hemmings op. cit.

${ }^{554} \mathrm{Ibid}$.

${ }^{555} \mathrm{Ibid}$

${ }_{556}^{55} \mathrm{Ibid}$.

${ }^{557}$ TH El Kadi. "The promise and peril of the digital silk road". Chatham House: The Royal Institute of International Affairs, 6 June, 2019. < https://www.chathamhouse. org/2019/06/promise-and-peril-digital-silk-road $>$ Accessed on 2 November 2021.

${ }^{558} \mathrm{Ibid}$.

${ }^{559}$ M Nouwens \& H Legarda. "China's pursuit of advanced dual-use technologies". International Institute for Strategic Studies (IISS), 18 December 2018. < https://www.iiss.org/blogs/ research-paper/2018/12/emerging-technology-dominance $>$ Accessed on 2 November 2021.

${ }^{560}$ DR Russel \& BH Berger. "Weaponizing the Belt and Road Initiative". Asia Society Policy Institute, September 2020.<https://asiasociety.org/sites/default/files/2020-09/ Weaponizing $\% 20$ the $\% 20$ Belt $\% 20$ and $\% 20$ Road $\% 20$ Initiative_0.pdf $>$ Accessed on 12 July 2021.

${ }^{561}$ See this link for China's AI development plan: https:/flia.org/wp-content/uploads/2017/07/ANew-Generation-of-Artificial-Intelligence-Development-Plan-1.pdf 